\title{
PENGARUH NET PROFIT MARGIN (NPM) DAN RETURN ON EQUITY (ROE) TERHADAP EARNING PER SHARE (EPS) PADA PT. SUPRA BOGA LESTARI TbK PERIODE 2011 - 2018
}

\author{
Faisal, S.E., M.M \\ Dosen universitas pamulang, \\ email: dosen00414@unpam.ac.id
}

\begin{abstract}
ABSTRAK
Kajian ini bertujuan untuk mengkaji pengaruh Margin Untung Bersih dan Ekuiti Return On Earning Per Share di PT Supra Boga Lestari Tbk pada tahun 2011-2018. Dalam kajian ini menggunakan kaedah kuantitatif di mana pemboleh ubah bebas dalam kajian ini adalah nisbah keuntungan seperti yang diukur oleh Margin Untung Bersih dan Ekuiti Pulangan. Sementara pemboleh ubah bersandar diukur dengan Perolehan Per Saham. Data yang digunakan dalam kajian ini adalah data sekunder dari laporan kewangan dalam tempoh 2011-2018. Kaedah analisis data yang digunakan adalah analisis regresi linier berganda dan pengujian hipotesis serta ujian asumsi klasik yang merangkumi ujian normalitas, ujian multikolineariti, ujian heteroskedisitas, dan ujian autokorelasi, dengan aras keertian 5\% alpha. Hasil kajian $\mathrm{t}_{\text {count }}(-1.049)<\mathrm{t}_{\text {tabel }}(2.571)$ menunjukkan bahawa pemboleh ubah NPM sebahagiannya mempunyai kesan negatif dan tidak signifikan terhadap EPS dengan nilai sig 0.342. Pemboleh ubah ROE dari tcount (6.317)> ttable (2.571) mempunyai kesan positif dan signifikan pada EPS dengan nilai sig 0.001. Sementara itu, secara serentak hasil NPM dan ROE $F_{\text {hitung }}>F_{\text {tabel }}(110,756>5,14)$ mempunyai pengaruh yang signifikan terhadap EPS dengan nilai sig 0,000. Jumlah pekali penentuan adalah 0.969. Ini bermaksud 96.9\% daripada pemboleh ubah bersandar, iaitu Perolehan Per Saham, dipengaruhi oleh pemboleh ubah tidak bersandar, iaitu Margin Untung Bersih dan Ekuiti Pulangan. Manakala baki 3.1\% dipengaruhi oleh pemboleh ubah lain yang tidak dikaji dalam kajian ini .
\end{abstract}

Kata kunci: Net profit margin (NPM), return on equity (ROE), earning per share (EPS)

\begin{abstract}
This study aims to examine the influence of Net Profit Margin and Equity Return On Earning Per Share at PT Supra Boga Lestari Tbk in 2011-2018. In this study using quantitative method where the independent variable in this study is profit ratio as measured by Net Profit Margin and Return Equity. While the dependent variable is measured by Earnings Per Share. The data used in this study are secondary data from the financial report for the period 2011-2018. The method of data analysis used is multiple linear regression analysis and hypothesis testing as well as classical assumption test which includes normality test, multicolineineity test, heteroscedity test, and autocorrelation test, with a significance level of 5\% alpha. The results of tcount study (-1.049) $<$ ttable (2.571) show that the NPM variable has partial negative and insignificant effect on EPS with sig value 0.342. The ROE variable from tcount (6.317)> ttable (2.571) had a positive and significant effect on EPS with a sig value of 0.001. Meanwhile, simultaneously the results of NPM and ROE Fhitung > Ftabel $(110,756>5,14)$ have a significant effect on EPS with a value of sig 0,000. The total determination coefficient is 0.969. This means that $96.9 \%$ of the dependent variables, i.e. Turnover Per Share, are influenced by the independent variables, namely Net Profit Margin and Return Equity. While the remaining 3.1\% was influenced by other variables not studied in this study.
\end{abstract}

Keywords: Net profit margin (NPM), return on equity (ROE), earnings per share (EPS) 


\section{PENDAHULUAN}

\section{A. Latar Belakang Penelitian}

Perkembangan perniagaan runcit di Indonesia terbahagi kepada 2, iaitu peruncitan tradisional dan peruncitan moden. Peruncitan tradisional adalah perniagaan yang dibina oleh pemerintah, pemerintah daerah, koperasi, perniagaan berskala kecil, modal kecil dan secara umum, banyak yang dalam proses membeli dan menjual barang dagangan mereka melalui tawar-menawar, seperti pasar tradisional dan toko kelontong. Runcit moden adalah kedai dengan sistem perkhidmatan bebas, menjual pelbagai jenis barang secara runcit dalam bentuk pasar mini, pasar raya, pasar raya, pasar raya besar atau kedai runcit.

Sejarah perkembangan runcit moden bermula dengan pendirian SARINAH Department Store di Jakarta. Sarinah adalah kedai sehenti atau "department store" pertama di Indonesia. Peletakan batu pertama dilakukan oleh Presiden Sukarno pada 17 Ogos 1962.

Untuk menunjang perkembangan dan peningkatan fasilitas pada perusahaan ritel seperti supermarket sebagai daya saing, perusahaan harus menjaga kestabilan kinerja finansialnya. Hal ini dapat menyebabkan nilai asetnya yang terus meningkat setiap tahunnya, selain itu juga sangat berpengaruh positif bagi perusahaan karena dapat meningkatkan mutu dan kualitas perusahaan bagi para investor bedasarkan tingkat pengembaliannya.

Beberapa perusahaan ritel ternama tidak jarang mengalami kesulitan dalam mengahasilkan laba ditengah ketatnya persaingan pada ruang lingkup yang sama. Sebuah perusahaan didirikan bertujuan untuk memperoleh laba/keuntungan. Sehingga perusahaan harus meningkatkan penjualannya.

Keupayaan syarikat untuk menjana keuntungan dapat diukur dengan laba yang maksimal dan dapat dilihat melalui rasio profitabilitasnya. Salah satu petunjuk yang digunakan untuk melihat kemampuan syarikat untuk memperoleh keuntungan adalah Net Profit Margin (NPM) untuk mengukur kemampuan syarikat untuk menjana keuntungan bersih dari setiap penjualan. Margin Untung Bersih Tinggi (NPM) menunjukkan bahawa prestasi syarikat semakin baik dan lebih produktif, serta kemampuan syarikat untuk memperoleh keuntungan yang tinggi.

Dan Return On Equity (ROE) adalah teknik lain untuk mengukur keuntungan syarikat dengan membandingkan pendapatan bersih syarikat dengan semua modalnya. Return On Equity (ROE) secara eksplisit menganalisis keuntungan berdasarkan penggunaan modal syarikat. Menurut Jumingan (2011) Return On Equity (ROE) digunakan untuk menentukan kemampuan syarikat untuk menjana pendapatan bersih melalui penggunaan modalnya sendiri. Sementara itu, menurut Harahap (2010) ROE digunakan untuk mengukur jumlah pulangan pelaburan pemegang saham .

Selain memperoleh keuntungan, 
syarikat ini juga bertujuan untuk mengoptimumkan nilai syarikat. Nilai firma adalah tahap kejayaan syarikat yang berkaitan dengan harga saham dan dapat diperoleh dari nilai per saham (Perolehan Per Saham) yang beredar dalam satu tempoh. Perolehan per saham (EPS) adalah nisbah pasaran yang digunakan untuk mengukur seberapa banyak pengiktirafan pasaran syarikat dengan membandingkan pendapatan bersih dengan jumlah saham yang masih ada di pasaran. Peningkatan EPS menunjukkan bahawa syarikat telah berjaya meningkatkan kesejahteraan pelabur dengan mengagihkan dividen (Tandelilin, 2010). Perolehan sesaham (EPS) dengan ringkasan menunjukkan prestasi syarikat berhubung dengan saham tertunggak. Pendapatan sesaham (EPS) yang berkaitan dengan harga pasaran saham (nisbah hargapendapatan) dapat memberikan gambaran keseluruhan prestasi syarikat berbanding dengan wang yang dilaburkan oleh pemilik syarikat .

PT. Supra Boga Lestari Tbk adalah Perusahaan bergerak di industri perdagangan ritel modern, dalam kategori fast moving consumer goods (FMCG) dan specialty products dengan format supermarket. Luas area supermarket perusahaan disekitar $700 \mathrm{~m} 2$ - $4.400 \mathrm{~m} 2$. Supermarket perusahaan menyediakan produk- produk kebutuhan sehari-hari yang meliputi fresh product (buahbuahan, sayur-sayuran, seafood dan daging) serta produk kebutuhan sehari-hari linnya termasuk produk organic, gluten free, dan dietary product.

Ranch Market dihadirkan dengan menawarkan produk-produk dengan kualitas premium dan mengedepankan keunikan dengan target pelanggan kalangan kelas atas dan menengah atas. Dengan pelayanan yang prima (service excellence), Ranch Market selalu memberikan pengalaman belanja yang menyenangkan, yang dapat dirasakan oleh pelanggan setiap kali berbelanja. Ranch Market dikenal sebagai supermarket yang melakukan kampanye untuk hidup sehat. Sesuai dengan taglinenya yaitu "It's a Balanced Life", pelanggan Ranch Market tidak hanya sekedar berbelanja tetapi juga mendapatkan edukasi tentang produk makanan dan hidup yang sehat dan seimbang.

Perusahaan mengimplementasikan sistem manajemen mutu dan keamanan makanan dengan menerapkan Hazard Analysis Critikal Control Point (HACCP) dan ISO 9001 sejak tahun 2003, yang selanjutnya ditingkatkan menerapkan ISO 22000 Food Safety Management System pada tahun 2008, yang telah disertifikasi ulang pada tanggal 1 September 2016 oleh SIA Global, badan sertifikasi berstandar internasional dari Australia. Penerapan HACCP dan ISO adalah untuk menjaga kualitas produk yang dijual di supermarket dan untuk meningkatkan proses operasional perusahaan.

Dalam upaya persaingan bisnis ritel PT. Supra Boga Lestari Tbk terus berusaha untuk melakukan peningkatan dasar perusahaan terutama dalam mendukung kegiatan operasionalnya, seperti aset, modal serta pendapatan perusahaan. 
Total aset dan total modal terendah terjadi pada tahun 2011. Hal ini dikarenakan perusahaan masih minim dalam penyebaran saham, modal, aset perusahaan serta besarnya hutang yang harus segera dibayarkan. Bahkan emiten ini juga melakukan penawaran umum perdana (IPO) dan memperoleh dana Rp149,75 miliar, di mana perseroan mengalokasikan Rp30 miliar untuk pembayaran utang kepada CIMB Niaga serta Rp29,9 miliar untuk pembayaran utang supplier dan biaya pra operasi toko baru.

Kemudian untuk total laba bersih pada tahun 2015 PT Supra Boga Lestari Tbk mencatatkan rapor merah, dimana total laba bersih tahun 2015 mengalami penurunan terbesar atau kerugian sebesar Rp -20,2 miliar. Hal ini di karenakan perusahaan menanggung beban pokok yang besar namun tidak diimbangi dengan pendapatan yang tinggi.

Berdasarkan uraian diatas maka penulis tertarik untuk melakukan penelitian dengan judul "Pengaruh Net Profit Margin (NPM) Dan Return On Equity (ROE) Terhadap Earning Per Share (EPS) Pada Perusahaan PT. Supra Boga Lestari Tbk Periode 20112018”.

\section{B. Rumusan Masalah}

1. Adakah pengaruh Net Profit Margin (NPM) terhadap Earning Per Share (EPS) pada PT. Supra Boga Lestari Tbk pada tahun 20112018 ?

2. Adakah pengaruh Return On Equity (ROE) terhadap Earning Per Share (EPS) pada PT.
Supra Boga Lestari Tbk pada tahun 2011 2018 ?

3. Adakah pengaruh Net Profit Margin (NPM) dan Return On Equity (ROE) terhadap Earning Per Share (EPS) PT. Supra Boga Lestari Tbk pada tahun 2011 -2018?

\section{TINJAUAN PUSTAKA}

\section{A. Landasan Teori}

Laporan keuangan (financial statement) menurut Herry (2016:5) "merupakan produk akhir dari serangkaian proses pencatatan dan pengikhtisaran data transaksi bisnis. Seorang akuntan diharapkan mampu untuk mengorganisir seluruh data akuntansi hingga menghasilkan laporan keuangan, dan bahkan harus dapat menginterpretasikan serta menganalisis laporan keuangan yang dibuatnya. Laporan keuangan pada dasarnya adalah hasil dari proses akuntansi yang dapat digunakan sebagai alat untuk mengkomunikasikan data keuangan atau aktivitas perusahaan kepada pihak-pihak yang berkepentingan. Dengan kata lain laporan keuangan ini berfungsi sebagai alat informasi yang menghubungkan perusahaan dengan pihak-pihak yang berkepentingan, yang menunjukan kondisi kesehatan keuangan perusahaan dan kinerja perusahaan".

\section{B. Rasio Profitabilitas/Rentabilitas}

Nisbah keuntungan atau disebut juga Rentability menerangkan kemampuan syarikat untuk memperoleh keuntungan melalui semua kemampuan dan sumbernya seperti aktiviti penjualan, wang tunai, modal, bilangan, pekerja, bilangan cawangan, dan sebagainya. Nisbah yang menggambarkan kemampuan 
syarikat untuk menjana keuntungan juga disebut Operating Ratio. Nisbah keuntungan adalah nisbah yang digunakan untuk mengukur kemampuan syarikat untuk menjana keuntungan dari aktiviti perniagaannya yang biasa .

\section{Return On Equity (ROE)}

Meenurut Kassmir

(2012:200-201)

"Return On Equity atau hasil pengembalian atas ekuitas atau rentabilitas modal sendiri merupakan rasio untuk mengukur laba bersih sesudah pajak dengan modal sendiri. Rasio ini menunjukan efisiensi penggunaan modal sendiri. Semakin tinggi hasil pengembalian atas ekuitas berarti semakin tinggi pula jumlah laba bersih yang dihasilkan dari setiap rupiah dana yang tertanam dalam ekuitas. Sebaliknya, semakin rendah hasil pengembalian atas ekuitas berarti semakin rendah pula jumlah laba bersih yang dihasilkan dari setiap rupiah dana yang tertanam dalam ekuitas".

\section{Earning Per Share (EPS)}

Menurut Kasmir (2014: 207) "Nisbah pendapatan sesaham atau juga dikenali sebagai nisbah nilai buku adalah nisbah untuk mengukur kejayaan pengurusan dalam mencapai faedah bagi pemegang saham. Nisbah yang rendah bermaksud bahawa pengurusan tidak berjaya memuaskan pemegang saham, sebaliknya, dengan nisbah yang tinggi, kesejahteraan pemegang saham meningkat .

\section{E. Pengembangan Hipotesis}

\section{Hipotesis Secara Parsial}

a. $\mathrm{Ho}_{1}$ : Diandaikan bahawa tidak ada pengaruh yang signifikan dari margin keuntungan bersih (NPM) terhadap Pendapatan Per Saham (EPS) .

$\mathrm{Ha}_{1}$ : Diduga terdapat kesan yang signifikan dari Margin Untung Bersih (NPM) terhadap Perolehan Per Saham (EPS)

b. $\mathrm{Ho}_{2}$ : Diandaikan bahawa tidak ada pengaruh signifikan Return On Equity (ROE) terhadap Earning Per Share (EPS) .

$\mathrm{Ha}_{2}$ : Diduga bahawa terdapat kesan signifikan Return On Equity (ROE) terhadap Earning Per Share (EPS) .

\section{Hipotesis Secara Simultan}

a. $\mathrm{Ho}_{3}$ : Diduga bahawa tidak ada pengaruh yang signifikan dari Margin Untung Bersih (NPM) dan Return On Equity (ROE) terhadap Perolehan Per Saham (EPS).

$\mathrm{Ha}_{3}$ : Diduga terdapat pengaruh yang signifikan dari Margin Untung Bersih (NPM) dan Return On Equity (ROE) terhadap Perolehan Per Saham (EPS).

\section{METODOLOGI PENELITIAN}

\section{A. Jenis Penelitian}

Penyelidikan ini berbentuk deskriptif kuantitatif, iaitu penyelidikan yang 
memberikan gambaran keseluruhan atau keterangan data yang dilakukan untuk menentukan hubungan antara pemboleh ubah bebas dan pemboleh ubah bersandar, di mana dalam kajian ini pemboleh ubah bebas $(\mathrm{X})$ adalah Margin Untung Bersih (NPM) dan Return. Pada Ekuiti (ROE) sementara pemboleh ubah bersandar (Y) adalah Perolehan Per Saham (EPS)

\section{B. Tempat dan Waktu Penelitian}

1. Tempat Penelitian

Penyelidikan ini dilakukan di Tangerang Selatan dengan mengambil data sekunder dari penyata kewangan syarikat PT. Supra Boga Lestari Tbk yang boleh didapati di laman web di alamat www.ranchmarket.co.id

2. Waktu Penelitian

Penyelidikan ini dilakukan dari November 2019 hingga Mac 2020. Data yang diambil adalah data penyata kewangan untuk tempoh 2011-2018 .

\section{Populasi dan Sampel}

1. Populasi

Populasi yang digunakan dalam kajian ini adalah penyata kewangan PT. Supra Boga Lestari Tbk .

2. Sample

Sampel yang digunakan dalam kajian ini adalah penyata kewangan dan kunci kirakira L / R di PT. Supra Boga Lestari Tbk .

\section{Teknik Analisis Data}

1. Uji Asumsi Klasik
a. Uji Normalitas Data
b. Uji Heteroskedastisiditas
c. Uji Multikolinearitas
d. Uji Autokorelasi

2. Uji Analisis Regresi

a. Analisis Regresi Linear Sederhana

b. Analisis Regresi Linier Berganda

3. Uji Koefisien Determinasi (R. Square)

4. Uji Hipotesis
a. Uji Parsial (Uji t)
b. Uji Simultan (Uji F)

IV. HASIL ANALISIS PENELITIAN dan PEMBAHASAN

\section{A. Hasil Statistik Deskriptif}

Hasil Analisis Deskriptif Data Descriptive Statistics

\begin{tabular}{|l|r|c|c|}
\hline & \multicolumn{1}{|c|}{ Mean } & $\begin{array}{c}\text { Std. } \\
\text { Deviation }\end{array}$ & N \\
\hline EPS & 20.25 & 14.390 & 8 \\
\hline NPM & 1.7100 & 1.37425 & 8 \\
\hline ROE & 6.9463 & 5.72599 & 8 \\
\hline
\end{tabular}

B. Hasil Uji Asumsi Klasik

\section{Hasil Uji normality Data}

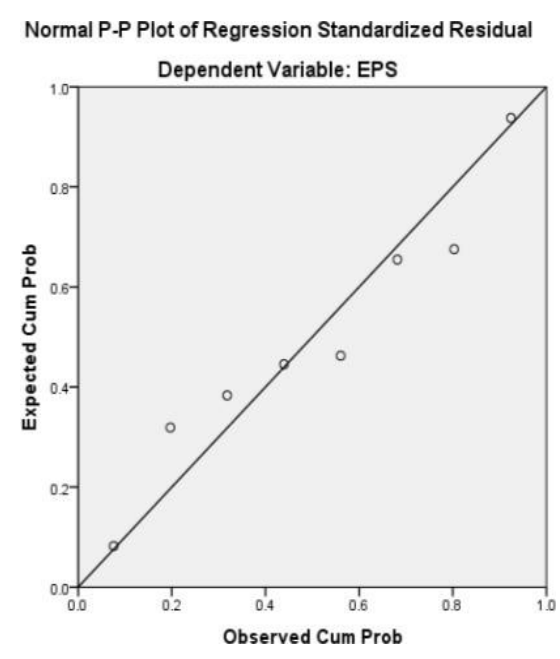

Hasil Uji Normality 
2. Uji Multikolinearitas

\section{Hasil Uji Multikolinearitas}

\begin{tabular}{|c|c|c|}
\hline \multicolumn{2}{|c|}{ Coefficients $^{2}$} \\
\hline \multirow{2}{*}{ Model } & \multicolumn{2}{|c|}{ Collinearity Statistics } \\
\cline { 2 - 3 } & Toleran ce & VIF \\
\hline (Constant) & & \\
\hdashline NPM & & \\
\hline ROE & 129 & \\
\hline 2. Dependent Variable:EPS & 129 & \\
\hline
\end{tabular}

2. Dependent Variable: EPS

\section{Uji heteroskedasitas}

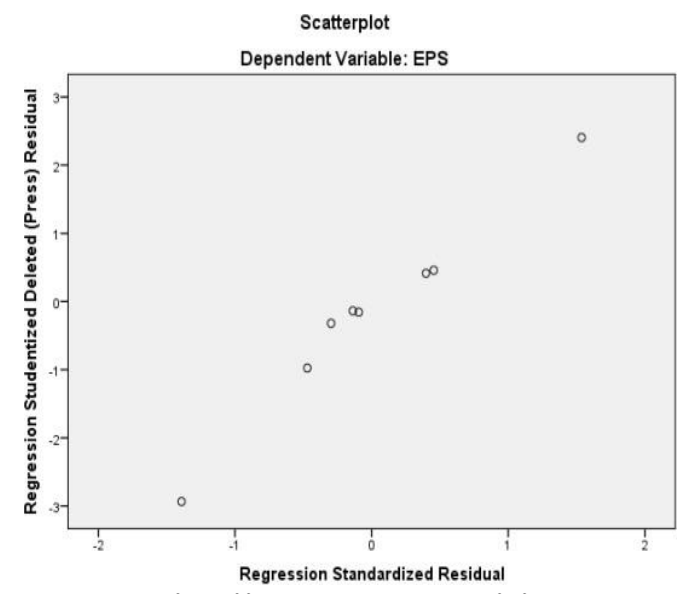

Hasil Uji Heteroskedastisitas

\section{Uji autokorelasi}

Hasil Uji Autokorelasi Dengan

Durbin-Watson

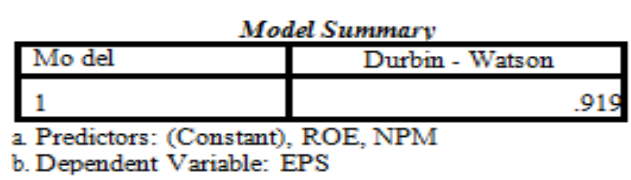

\section{Hasil Uji Autokorelasi Dengan Runs Test}

\begin{tabular}{|c|c|}
\hline \multicolumn{2}{|c|}{ Runs Test } \\
\hline & $\begin{array}{c}\text { Unstandardized } \\
\text { Residual }\end{array}$ \\
\hline Test Value & -.29278 \\
\hline Cases < Test Value & 4 \\
\hline Cases $>=$ Test Value & 4 \\
\hline Total Cases & 8 \\
\hline Number of Runs & 6 \\
\hline Z & 382 \\
\hline Asymp. Sig. (2-tailed) & .703 \\
\hline
\end{tabular}

\section{Uji Analisis Regresi}

1. Hasil Analisis Regresi Linear Sederhana

a. Pengaruh Net Profit Margin (NPM) Terhadap Earning Per Share

\begin{tabular}{|c|c|c|c|}
\hline \multicolumn{4}{|c|}{ Coefficients } \\
\hline \multirow[t]{2}{*}{ Model } & \multicolumn{2}{|c|}{$\begin{array}{l}\text { Unstandardized } \\
\text { Coefficients }\end{array}$} & $\begin{array}{l}\text { Standardized } \\
\text { Coefficients }\end{array}$ \\
\hline & $\mathrm{B}$ & Std. Error & Beta \\
\hline (Constant) & 2,074 & 4,292 & \\
\hline NPM & 9,964 & 2,006 & 897 \\
\hline
\end{tabular}

Dari jadual di atas, persamaan regresi linear sederhana yang terbentuk ialah $\mathrm{Y}=$ $2.074+9.964$ X1. Maknanya: Margin Untung Bersih mempunyai arah positif ke arah Perolehan Per Saham.

Tafsiran persamaan regresi linear sederhana di atas adalah seperti berikut:

a. Pemalar yang terhasil dari pengiraan di atas adalah 2.074. Ini menunjukkan bahawa jika nilai Margin Untung Bersih sama dengan sifar (0), maka pemboleh ubah bersandar Perolehan sesaham akan berubah menjelang 2.074 .

b. Pemboleh ubah Margin Untung Bersih mempunyai nilai pekali 9.964 dan positif. Ini bermakna bahawa jika Margin Untung Bersih telah meningkat sebanyak $1 \%$ dan pemboleh ubah bebas adalah tetap, nilai Perolehan Per Saham akan meningkat sebanyak 9.964 .

b. Pengaruh Return On Equity (ROE) Terhadap Earning Per Share (EPS)

\begin{tabular}{|c|c|c|c|c|}
\hline \multicolumn{5}{|c|}{ Coefficients $^{a}$} \\
\hline \multirow{2}{*}{\multicolumn{2}{|c|}{ Model }} & \multicolumn{2}{|c|}{$\begin{array}{l}\text { Unstandardized } \\
\text { Coefficients }\end{array}$} & $\begin{array}{l}\text { Standardized } \\
\text { Coefficients }\end{array}$ \\
\hline & & $B$ & $\begin{array}{l}\text { Std. } \\
\text { Error }\end{array}$ & Beta \\
\hline 1 & (Constant) & 830 & 1,531 & \\
\hline & ROE & 2,632 & 175 & 987 \\
\hline
\end{tabular}


Dari tabel di atas diperoleh hasil persamaan regresi linier sederhana yang terbentuk adalah $\mathrm{Y}=0,830+2,632 \mathrm{X}_{2}$. Artinya : Return On Equity memiliki arah hubungan positif terhadap Earning Per Share.

Interpestasi dari persamaan regresi liniear sederhana di atas adalah sebagai berikut:

a. Konstanta yang dihasilkan dari perhitungan di atas yaitu sebesar 0,830.

Hal ini menjukan apabila nilai dari Return On Equity sama dengan nol (0), maka variabel dependen Earning per Share akan mengalami perubahan sebesar 0,830 .

b. Variabel Return On Equity menpunyai nilai koefisien sebesar 2,632 dan bertanda positif. Hal ini berarti apabila Return On Equity mengalami peningkatan sebesar $1 \%$ dan variabel independen bersifat tetap, maka nilai Earning Per Share akan mengalami peningkatan sebesar 2,632.

\section{Hasil Analisis Regresi Linier Berganda}

\section{Hasil Uji Analisis Regresi Linear Berganda}

\begin{tabular}{|c|r|r|c|}
\hline \multirow{3}{*}{ Model } & \multicolumn{4}{|c|}{$\begin{array}{c}\text { Coefficients } \\
\text { Unstandardized } \\
\text { Coefficients }\end{array}$} & $\begin{array}{c}\text { Standardizad } \\
\text { Coefficients }\end{array}$ \\
\cline { 2 - 4 } & \multicolumn{1}{|c|}{ B } & Std. Error & Beta \\
\hline (Constan t) & 3.343 & 1.495 & \\
\hdashline NPM & -2.030 & 1.935 & -194 \\
\hline ROE & 2.934 & .464 & 1.167 \\
\hline a. Dependent Variable: EPS & &
\end{tabular}

\section{Persamaan Regresi :}

$\mathrm{Y}=3,343-2,030 \mathrm{X}_{1}+2,934 \mathrm{X}_{2}$ Atau

Earning Per Share $=3,343-2,030 \mathrm{Net}$ Profit Margin + 2,934 Return On Equity

\section{Hasil Koefisien Determinas}

\section{Hasil Uji Koefisien Determinasi}

\begin{tabular}{|c|c|r|r|r|}
\hline Mod el & $R$ & R Square & $\begin{array}{c}\text { Adjusted R } \\
\text { Square }\end{array}$ & $\begin{array}{c}\text { Std. Error of } \\
\text { the Estimate }\end{array}$ \\
\hline 1 & $.989^{2}$ & .978 & .969 & 2.530 \\
\hline
\end{tabular}
a. Predictors: (Constant), ROE, NPM

Berdasarkan jadual di atas, ini menunjukkan pekali penentuan ( $\mathrm{R}$ square) dan pekali (Adjusted R squarre). Nilai R square menerangkan tahap hubungan antara pemboleh ubah bebas (X) dan pemboleh ubah bersandar (Y). Dari data yang diproses, pekali penentuan adalah 0.978 atau sama dengan 97.8\%, yang bermaksud bahawa nisbah NPM dan ROE mempunyai pengaruh pada $97.8 \%$ EPS. Sementara itu, $2.2 \%$ dipengaruhi oleh pemboleh ubah lain yang tidak dikaji dalam kajian. The $\mathrm{R}$ square menerangkan berapa banyak variasi $\mathrm{X}$ yang dibebaskan oleh $\mathrm{X}$ dari hasil pengiraan yang diperoleh dengan nilai Adjusted R Square sebanyak 0.969 atau 96.9\%, yang bermaksud bahawa $96.9 \%$ EPS dipengaruhi oleh kedua-dua pemboleh ubah NPM dan ROE. Dan baki 3.1\% dipengaruhi oleh pemboleh ubah lain yang tidak dikaji dalam kajian ini .

\section{E. Hasil Uji Hipotesis}

\section{Hasil Uji Secara Partial (Uji-t) Hasil Uji (t)}




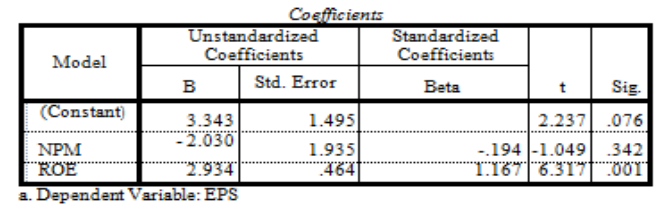

a. Hasil uji parsial NPM terhadap EPS

Berdasarkan jadual di atas, dalam pemboleh ubah NPM di atas, nilai jumlah adalah -1.049, sementara jadual $\mathrm{t}$ dengan tahap kepentingan $5 \%$ dan darjah kebebasan $(\mathrm{dk})=\mathrm{n}-\mathrm{k}=8-2=6$ adalah 2.571. Dengan membuat perbandingan, iaitu tcount (-1.049) $<$ ttable (2.571) dan dilihat dari jadual di atas, dapat juga dilihat bahawa bilangan signifikannya adalah 0.342 yang bermaksud angka ini lebih besar daripada aras keertian $(0.342>0.05)$, maka perubahan NPM separa tidak mempunyai kesan yang signifikan terhadap perubahan EPS. Ini bermaksud bahawa NPM tidak dapat meningkatkan atau menambah nilai pada EPS .

\section{b. Hasil uji parsial ROE terhadap EPS}

Berdasarkan jadual di atas, pemboleh ubah ROE di atas menunjukkan nilai jumlah 6.337 manakala jadual $\mathrm{t}$ dengan aras keertian $5 \%$ dan darjah kebebasan $(\mathrm{dk})=\mathrm{n}-\mathrm{k}=$ 8-2 $=6$ adalah 2.571. Dengan membuat perbandingan, iaitu tcount (6.337)> ttable (2.571) dan dilihat dari jadual di atas, dapat juga dilihat bahawa bilangan signifikannya adalah 0.001 yang bermaksud angka ini lebih besar daripada aras keertian $(0.001<0.05)$, maka perubahan ROE sebahagiannya mempunyai pengaruh yang signifikan kepada perubahan dalam EPS. Ini bermaksud bahawa ROE dapat meningkatkan atau menambah nilai pada EPS .

\section{Hasil Uji Secara Simultan(Uji-F)} Hasil Uji (F)

\begin{tabular}{|c|c|c|c|c|c|c|}
\hline \multicolumn{7}{|c|}{ ANOVA $^{\mathrm{a}}$} \\
\hline \multicolumn{2}{|c|}{ Model } & $\begin{array}{l}\text { Sum of } \\
\text { Squares }\end{array}$ & $\mathrm{Df}$ & $\begin{array}{l}\text { Mean } \\
\text { Square }\end{array}$ & $\mathrm{F}$ & Sig. \\
\hline & Regression & 1417.504 & 2 & 708.752 & 110.756 & $.000^{b}$ \\
\hline 1 & Residual & 31.996 & 5 & 6.399 & & \\
\hline & Total & 1449.500 & 7 & & & \\
\hline
\end{tabular}

Berdasarkan hasil pengujian Analysis of Variance (ANOVA) diatas diperoleh nilai $F_{\text {hitung }}$ sebesar 110,756 dengan signifikansi 0,000 . Sedangkan pada $\mathrm{F}_{\text {tabel }}$ dengan signifikansi $5 \%$ dan $\mathrm{dfl}=\mathrm{k}=2, \mathrm{df} 2=\mathrm{n}-\mathrm{k}-1=8-2-1=5$, diperoleh $\mathrm{F}_{\text {tabel }}$ sebesar 5,14. Dengan demikian $\mathrm{F}_{\text {hitung }}$ lebih besar dari $\mathrm{F}_{\text {tabel }}$ $(110,756>5,14)$ dan nilai signifikan lebih kecil dari a $=0,05(0,000<0,05)$, yang berarti variabel NPM dan ROE berpengaruh signifikan secara simultan terhadap EPS (Earning Per Share). Artinya bahwa secara bersama-sama variabel NPM dan ROE mampu menaikkan atau memberi nilai tambah pada EPS.

\section{PENUTUP}

\section{A. Kesimpulan}

1. Sebahagiannya, bahawa Margin Untung Bersih (NPM) tidak terbukti mempunyai kesan yang signifikan terhadap Perolehan 
Per Saham (EPS), ini kerana jumlah $\mathrm{t}$ adalah -1.049 atau lebih kecil daripada jadual-t 2.571. Nilai ketara ialah 0.342> 0.05. Ini bermakna bahawa jika Margin Untung Bersih (NPM) meningkat, maka Perolehan Per Saham (EPS) akan menurun. Jadi dapat disimpulkan bahawa Ho1 diterima dan Ha1 ditolak .

2. Return On Equity (ROE) terbukti memberi kesan kepada Earning Per Share (EPS). Di mana Return On Equity (ROE) mempunyai kesan positif dan signifikan terhadap Earning Per Share (EPS), ini bermakna jika Return On Equity (ROE) meningkat, maka Earning Per Share (EPS) akan meningkat. Nilai penghitungan adalah 6.317 atau lebih besar daripada jadual 2.571 dan nilai signifikan 0.001 $<0.05$ atau mempunyai kesan yang signifikan terhadap Perolehan Per Saham (EPS). dapat disimpulkan bahawa Ho2 ditolak dan Ha2 diterima .

3. Ujian serentak membuktikan bahawa kedua-dua Net Proofit Margin (NPM) dan Return On Equity (ROE) mempunyai kesan yang signifikan terhadap Earning Per Share (EPS). Ini dibuktikan dengan ujian F di mana Fcount 110.756 lebih besar daripada Ftable 5.14. Begitu juga, dengan nilai keertian 0,000 atau kurang daripada aras keertian yang ditentukan 0,05, dapat disimpulkan bahawa $\mathrm{Ho} 3$ ditolak dan Ha3 diterima. Pengaruh dua pemboleh ubah tidak bersandar pada
Perolehan Per Saham (EPS) adalah 96.9\%, sementara baki $3.1 \%$ dipengaruhi oleh pemboleh ubah lain yang tidak dikaji dalam kajian ini .

\section{B. Saran}

1. Bagi Perusahaa

Syarikat harus meningkatkan lagi prestasi kewangannya sehingga dapat menghasilkan keuntungan yang terus meningkat setiap tahun dan menjaga kestabilan keuntungan syarikat, serta memperhatikan semua aspek yang mempengaruhinya. Kerana dalam pelaburan, pelabur cenderung memperhatikan berapa banyak keuntungan yang menjadi hak pemilik modal (saham) mereka sendiri dan berapa pulangan pelaburan sesaham.

2. Bagi Penelitian Berikutnyya

Penelitian ini bisa menjadi referensi untuk penelitian selanjutnya, diharapkan pada penelitian selanjutnya variabel-variabel, tahun, dan perusahaan yang lebih beragam atau berbeda sehingga penelitian tersebut akan menghasilkan suatu informasi atau pengetahuan yang baru. Selain itu bagi peneliti selanjutnya diharapkan mampu menggunakan metode analisis yang lain sehingga hasil penelitian bisa lebih akurat lagi. Jangka waktu penelitian juga diharapkan tidak terbatas hanya 8 tahun saja tetapi lebih.

\section{DAFTAR PUSTAKA}

Darsono,P. (2010). Pedoman Memahami 
Laporan Keuangan Edisi 1. Yogyakarta: Diadit Media .

Fahmi, I. (2012). Manajemen Keuangan Perusahaan dan Pasar Modal. Jakarta: Mitra Wacana Media .

Fahmi, I. (2013). Rahasia Saham dan Obligasi. Bandung: Alfabeta .

Fahmi, I. (2014). Pengantar Pasar Modal Cetakan Bandung: Alfabeta .

Harahap, S.S. (2010). Analisis Kritis Atas Laporan Keuangan. Jakarta: PT Raja Grasindo Persada .

Harahap, S.S. (2015). Analisis Kritis Atas Laporan Keuangan. Jakarta: PT Raja Grasindo Persada .

Hasibuan, Melayu S.P. (2016). Manajemen Dasar, Pengertian, dan Masalah Edisi Revisi cetakan tujuh. Jakarta: PT Bumi Askara .

Hery. (2016). Mengenal dan Memahami Dasardasar Laporan Keuangan. Jakarta: PT Grasindo. Hery. (2015). Analisis Laporan Keuangan Edisi 1. Yogyakarta: Center For Academic publishing service .

Jumingan. (2011). Analisis Laporan Keuangan. Jakarta: Bumi Askara .

Kamaludin., \& Indriani. (2012). Manajemen Keuangan Edisi Revisi. Bandung: CV Mandar Maju .

Kasmir. (2010). Pengantar Manajemen Keuangan Edisi 1 Cetakan 2. Jakarta: Kencana Media Perdana Group .

Kasmir. (2012). Analisis Laporan Keuangan Edisi 1 Cetakan 7. Jakarta: Rajawali Pers .

Martono. (2010). Manajemen Keuangan. Yogyakarta: Ekonisia .
Murhadi, W.R. (2013). Analisis Laporan Keuangan, Proyeksi dan Valuasi Saham. Jakarta: Salemba Empat .

Prihadi, T. (2011). Analisis Laporan Keuangan Teori dan Aplikasi. Jakarta: PPM .

Priyatno, D. (2012). Paham Analisis Statistika Data dengan SPSS 20. Yogyakarta: C.V Andi OFFSET .

Priyatno, D. (2014). SPSS 22 Pengolahan Data Terpraktis.Yogyakarta: CV Andi Offset

Safroni, S., \& Freeman. (2012). Manajemen. Jakarta: Intermedia .

Sarwono, J. (2012). Metode Penelitian Kuantitatif dan Kualitatif. Yogyakarta: Graha Ilmu .

Sugiyono. (2010). Metode Penelitian Kuantitatif dan Kualitatif $\mathrm{R}$ dan $\mathrm{D}$. Bandung: Alfabeta .

Sugiyono. (2013). Metode Penelitian Kombinasi (Mixed Methods) Cetakan 3. Bandung: Alfabeta .

Sutrisno. (2012). Teori Manajemen Keuangan, Konsep dan Aplikasi. Yogyakarta: Ekonisia .

Terry, G.R. (2010). Dasar-Dasar Manajemen. Jakarta: Bumi Askara .

Terry, G.R. (2016). Dasar-dasar Perbankan Edisi Revisi. Jakarta: Bumi Askara .

Usman, H. (2013). Manajemen Teori, Praktik dan Riset Pendidikan Edisi 4. Jakarta: Bumi Askara .

Cahyani, M. A., Isynuwardhana, D., \& Mahardika .

D. P. K. (2017). Pengaruh Return On Asset 
(ROA), Return On Equity (ROE), dan Earning Per Share (EPS) Terhadap Harga Saham (Studi pada Perusahaan Manufaktur Sektor Industri Barang Konsumsi yang Terdaftar di Bursa Efek Indonesia Periode 2011-2015). E-Proceeding Of Management, 4(1) .

Dwiatmanto, \& Yaningwati, F. (2013). Pengaruh Financial Laverage (DR, DER, dan DFL) Terhadap Earning Per Share (EPS). Jurnal Administrasi Bisnis 1(1), 95-103

Ismail, W., Tommy, P., \& Untu, V. (2016). Pengaruh Current Ratio dan Struktur Modal Terhadap Laba Per Lembar Saham (EPS) pada Perusahaan Pertambangan BatuBara yang Terdaftar di BEI. Jurnal Manajemen \& Bisnis, 16(01), 469-480 .

Nugroho, H., \& Krisnaldy, K. (2019). PENGARUH INFLASI, GROSS DOMESTIC PRODUCT, BIAYA OPERASIONAL DAN PENDAPATAN OPERASIONAL TERHADAP PROFITABILITAS PADA PERUSAHAAN PERBANKAN SYARIAH DI INDONESIA PERIODE 2012-2015. Jurnal Semarak, 2(3), 108-125.

Manoppo, V. Ch. O., Tewal, B., \& Hasan Jan, A. B. (2017). Pegaruh Current Ratio (CR), Debt to Equity Rato (DER), Return On Asset (ROA) dan Net Profi Margin (NPM) terhadap Harga Saham pada Peusahaan Food and Beverages yang Terdaftar di BEI (Periode 2013-2015). Jurnal EMBA, 5(2), 1813-1822, ISSN : 2303-1174 .

Nordiana, A., \& Budiyanto. (2017). Pengaruh Debt to Equity Ratio, Return On Asset dan Return On Equity terhadap Harga Saham pada Perusahaan Food and Beverage di Bursa Efek Indonesia. Jurnal Ilmu dan Riset Manajemen, 6(2), 1-16, E-ISSN: 2461-0593 .

Diaz, R., \& Jufrizen. (2014). Pengaruh Return On Asset (ROA), Return On Equity (ROE) Terhadap Earning Per Share (EPS) pada
Perusahaan Asuransi yang Terdaftar di Bursa Efek Indonesia. Jurnal Manajemen \& Bisnis, 14(02), 127-134, ISSN : 16937619

Purnomo, S., \& Pasaribu, V. L. D. (2019). Pergerakan Harga Saham Pt Adaro Energy Tbk (Adro) Pada Pengumuman Dividen Interim Tahun Buku 2018. Jurnal Ekonomi Efektif, 2(1).

Rahmadewi, P.W., \& Abundanti, N. (2018). Pengaruh EPS, PER, CR, dan ROE Terhadap Harga Saham di Bursa Efek Indonesia. E-Jurnal Manajemen Unud, 7(4), 2106-2133, ISSN : 2302-8912 .

Safitri, A. M., \& Mukaram. (2018). Perngaruh ROA, ROE, dan NPM Terhadap Pertumbuhan Laba Pada Perusahaan Sektor Industri Barang Konsumsi yang Terdaftar di Bursa Efek Indonesia. Jurnal Riset Bisnis dan Investasi, 4(1), 25-39, ISSN : 2460-8211 .

Sari, L. R., \& Sugiyono. (2016). Pengaruh NPM, ROE, EPS Terhadap Return Saham pada Perusahaan Farmasi di BEI. Jurnal Ilmu dan Riset Manajemen, 5(12), 1-18, ISSN : 2461-0593 .

Tumanggor, M., Satria, R., Jamaludin, D. N. R. P., \& Oktrima, B. (2020). Effect of Costs and Operational Income (Bopo), Capital Adequacy Ratio (Car), and Net Performing Loan (Npl) For Return on Asset (Roa)(Empirical Study of Go Public Banking 2011-2017). Solid State Technology, 63(6), 1390-1396.

https://junaidichaniago.wordpress.com https://www.idx.co.id https://www.ranchmarket.co.id/assets/uplo ads/brochure/LK.pdf 